\title{
Acquired pachydermatoglyphia: the cutaneous manifestation of pulmonary tumours
}

\author{
Hugo Jorge Casimiro, ${ }^{1,2}$ Joana Carreira, ${ }^{1}$ Beatriz Navarro, ${ }^{1}$ Mário Parreira ${ }^{1}$
}

'Department of Internal

Medicine, Centro Hospitalar de Setubal EPE, Setúbal, Portugal

${ }^{2}$ Instituto de Histologia e

Biologia do Desenvolvimento, Universidade de Lisboa

Faculdade de Medicina, Lisboa, Portugal

\section{Correspondence to}

Dr Hugo Jorge Casimiro,

hugojorgecasimiro@gmail.com

Accepted 4 July 2017

\section{CrossMark}

To cite: Casimiro $\mathrm{HJ}$ Carreira J, Navarro B, et al. BMJ Case Rep Published Online First: [please include Day Month Year] doi:10.1136/bcr-2017220843

\section{DESCRIPTION}

A 74-year-old man with active smoking habits presented to the emergency department with a 2 -month history of weight loss (20\% of previous body mass), dyspnoea and night sweats. Physical examination showed clinical signs of respiratory distress, significant cachexia and thickened velvety palms with pronounced folds (figure 1). The laboratory results revealed leucocytosis of $15700 \mathrm{cells} / \mu \mathrm{l}$, thrombocytosis of $547000 / \mu \mathrm{l}$ and elevated $C$ reactive protein of $6.65 \mathrm{mg} / \mathrm{dL}$. A posteroanterior chest radiograph showed a right pleural effusion and consolidation suggestive of pneumonia.

The patient was given antibiotics and submitted to pleural effusion drainage for symptomatic relief. A skin biopsy of the palms was obtained and the histopathological examination identified signs of hyperkeratosis, acanthosis and papillomatosis consistent with acquired pachydermatoglyphia (figure 2).

After clinical improvement, a thoracic CT scan revealed a large mass in the inferior right lung lobe, multiple pretracheal and precarinal lymphadenopathies and multiple bilateral pulmonary nodular lesions suggestive of stage IV lung cancer. The patient was admitted to a palliative care unit and he died 6 months later.

Paraneoplastic dermatoses are a group of cutaneous manifestations that occur concurrently with some malignancies. They follow a similar course as the tumours and share a genetic basis with them. They are sometimes the first sign of malignancy. ${ }^{1}$

Acquired pachydermatoglyphia (also known as tripe palms) is a proliferative paraneoplastic

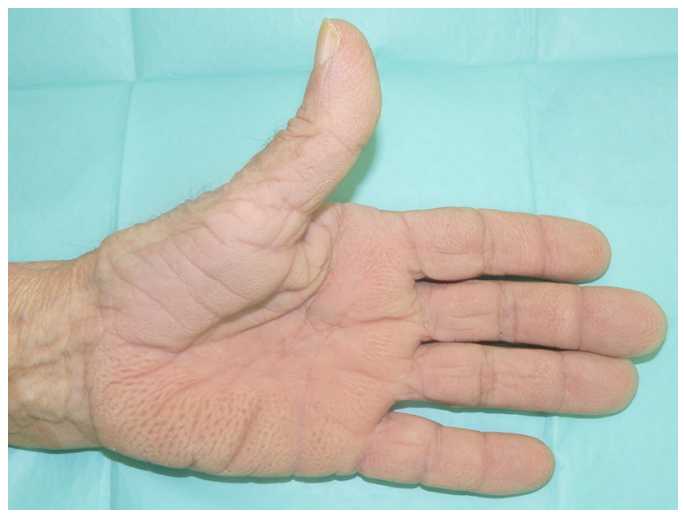

Figure 1 Thickened velvety palms with pronounced folds consistent with acquired pachydermatoglyphia.

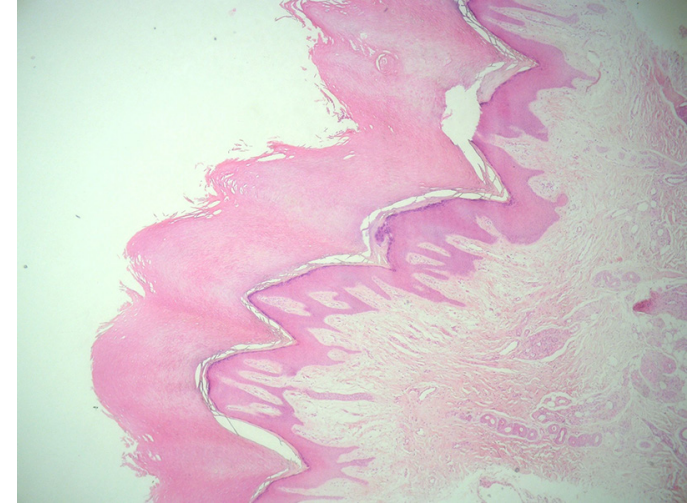

Figure 2 Skin biopsy consistent with acquired pachydermatoglyphia, showing hyperkeratosis, acanthosis and papillomatosis.

\section{Learning points}

- Paraneoplastic dermatoses occur concurrently with some malignancies.

- They are sometimes the first sign of malignancy.

- Acquired pachydermatoglyphia is highly associated with lung and gastric cancer.

dermatosis ${ }^{2}$ that is highly associated with lung and gastric cancer. ${ }^{3}$ In some series, it was identified prior to the tumour in up to $40 \%$ of the patients.

Acknowledgements Rui Bajanca for providing the histopathological images.

Contributors HJC was responsible for the overall content, including planning, conduct and reporting of the work. JC was responsible for the planning and conduct of the work, including literature search, figures and data collection. BN was responsible for conduct and reporting of the work. MP was responsible for the reporting of the work.

Competing interests None declared.

Patient consent Obtained.

Provenance and peer review Not commissioned; externally peer reviewed.

(C) BMJ Publishing Group Ltd (unless otherwise stated in the text of the article) 2017. All rights reserved. No commercial use is permitted unless otherwise expressly granted.

\section{REFERENCES}

1 Thiers BH, Sahn RE, Callen JP. Cutaneous manifestations of internal malignancy. CA Cancer J Clin 2009;59:73-98.

2 Cohen PR, Grossman ME, Almeida L, et al. Tripe palms and malignancy. J Clin Oncol 1989;7:669-78.

3 Owen CE. Cutaneous manifestations of lung cancer. Semin Oncol 2016:43:366-9 
Copyright 2017 BMJ Publishing Group. All rights reserved. For permission to reuse any of this content visit http://group.bmj.com/group/rights-licensing/permissions.

BMJ Case Report Fellows may re-use this article for personal use and teaching without any further permission.

Become a Fellow of BMJ Case Reports today and you can:

- Submit as many cases as you like

- Enjoy fast sympathetic peer review and rapid publication of accepted articles

Access all the published articles

- Re-use any of the published material for personal use and teaching without further permission

For information on Institutional Fellowships contact consortiasales@bmjgroup.com

Visit casereports.bmj.com for more articles like this and to become a Fellow 